J. Clin. Chem. Clin. Biochem.

Vol. 16, 1978, pp. 307-311

\title{
Determination of Perazine Serum Levels by Gas Liquid Chromatography under Clinical Routine Conditions
}

By J. Schley, E. Riedel, and B. Müller-Oerlinghausen

Institute of Biochemistry and Department of Psychiatry. Free University of Berlin

(Received September 13, 1977/January 18, 1978)

Summary: A quantitative gas liquid chromatographic method for the determination of serum levels of perazine (10-[ $3^{\prime}-\left(1^{\prime \prime}-\right.$-methyl-4" -piperazinyl)-propyl]-phenothiazine) is described. Perazine is used as a neuroleptic drug. The main problem consists in optimizing the chromatographic system. A sensitivity of appr. $60-150 \mathrm{nmol} / \mathrm{l}$ $(20-50 \mu \mathrm{g} / \mathrm{l})$ serum is achieved. Examples of optimization, analyses with patient samples, and the reproducibility of the results are presented.

\section{Gasliquidchromatographische Bestimmung der Perazin-Konzentration im Serum unter klinischen Routine- bedingungen}

Zusammenfassung: Es wird eine quantitative gasliquidchromatographische Methode zur Bestimmung von Perazin (10-[3'-(1"-Methyl-4"-piperazinyl)-propyl]-phenothiazin) im Serum beschrieben. Perazin wird als Neuroleptikum eingesetzt. Das methodische Hauptproblem ist die Optimierung des chromatographischen Systems, wodurch eine Empfindlichkeit bis zu 59-148 nmol/1 (20-50 $\mu \mathrm{g} / \mathrm{l})$ erreicht wird. Reproduzierbarkeit und praktische Anwendbarkeit unter klinischen Bedingungen werden dargestellt.

\section{Introduction}

The quantitative determination of perazine (10-[3'( $1^{\prime \prime}$-methyl-4"-piperazinyl)-propyl]-phenothiazine ${ }^{1}$ ) in human serum samples under clinical routine conditions presents an analytical problem which has not yet found a satisfactory solution. Therapeutic serum levels of perazine can be expected to be within the range of approx. 59-885 nmol/1 (20-300 $\mu \mathrm{g} / 1)(1)$. Spectrophotometric and fluorometric methods are unsuitable, owing to the codetermination of metabolites $(2,3)$. The chromatographic separation of serum eluates is an indispensable prelude to the detection step, but this entails a loss of material and reduced sensitivity. The autoxidability of the phenothiazines provides' additional analytical problems.

Breyer \& Villumsen (1) have developed a direct densitometric thin layer chromatographic method, which has been shown to be very sensitive but also rather timeconsuming (4). The use of gas liquid chromatography (GLC) entails some special difficulties, which are

1) Taxilan, Promonta, D-2000 Hamburg 26 described in detail below. The very sensitive electron capture detectors, which have been used for determination of phenothiazine derivatives such as chlorpromazine or perphenazine, cannot be applied in the case of perazine. For the determination of 20-50 ng perazine by use of the FID, however, the analytical procedure must be fully optimized. In the method published recently by Vanderheeren et al. (5) most of the steps are not optimized, so that determinations are limited to samples containing from $1.47 \mathrm{nmol}$ ( $=100 \mu \mathrm{g} / 1$ serum with $5 \mathrm{ml}$ serum extracted) upwards. It is, however, possible, to perform $20 \mathrm{GLC}$ determinations of perazine daily per column with a lower detection limit of $59 \mathrm{nmol} / 1(20 \mu \mathrm{g} / \mathrm{l})$, providing the following optimization procedures are taken into consideration.

\section{Material and Methods}

Material

All reagents were Merck p.a. quality. Silicone XE 60, Silicone OV-12, dichlormethylsilane, Chromosorb $G$ and Gaschrome Q 80/100; 100/120 mesh were ordered from WGA-Düsscldorf. 
Procedure

Preparation of glass vessels

Cleaning of all glass vessels should be done without detergents. All glass vessels, after being cleaned with hot water, are boiled in about $6 \mathrm{~mol} / 1 \mathrm{HCl}$, rinsed with double distilled water, dried, and treated with $50 \mathrm{ml} / 1$ dichloromethane in toluene. They are

\section{Extraction}

$5 \mathrm{ml}$ serum (deep frozen at $-15^{\circ} \mathrm{C}$ and thawed shortly before processing) with addition of $1 \mathrm{ml}$ of $1 \mathrm{~mol} / 1 \mathrm{NaOH}$ are kept in a boiling water bath for $15 \mathrm{~min}$, then cooled down to room temperature and extracted 3 times with $5 \mathrm{ml} n$-heptane. The combined extracts are evaporated at room temperature or with light heating (not $>35^{\circ} \mathrm{C}$ ) under nitrogen.

\section{Analysis}

GLC was performed with a Varian $1520 \mathrm{~B}$ using flame ionisation detectors. Column: glass, $190 \mathrm{~cm}, 4 \mathrm{~mm} \phi$, silanized, packed with $3 \%$ silicone OV-17 on Gaschrome Q 100/120 mesh. Injection port: $270^{\circ} \mathrm{C}$ detector: $300^{\circ} \mathrm{C}$. Oven: $270^{\circ} \mathrm{C}$. Carrier gas" flow $30 \mathrm{ml}$ $\mathrm{N}_{2} / \mathrm{min}$. $\mathrm{H}_{2}: 30 \mathrm{ml} / \mathrm{min}$. Air: $300 \mathrm{ml} / \mathrm{min}$. Attenuation 2 or $4 \times 10^{-11}$. The evaporated heptane extracts are taken up with $25 \mu \mathrm{l}$ standard solution (internal standard: $48.46 \mathrm{nmol} / \mathrm{l}$ stigmasterol in ethanol); they must be kept cool at $0-4^{\circ} \mathrm{C}$ and tightly closed until injection. After careful stirring with a spatula $1 \mu \mathrm{l}$ is injected. The column is checked daily by running a calibration curve. The quantitative evaluation is performed by peak height comparison. dried finally at $120^{\circ} \mathrm{C}$ for 1 hour.

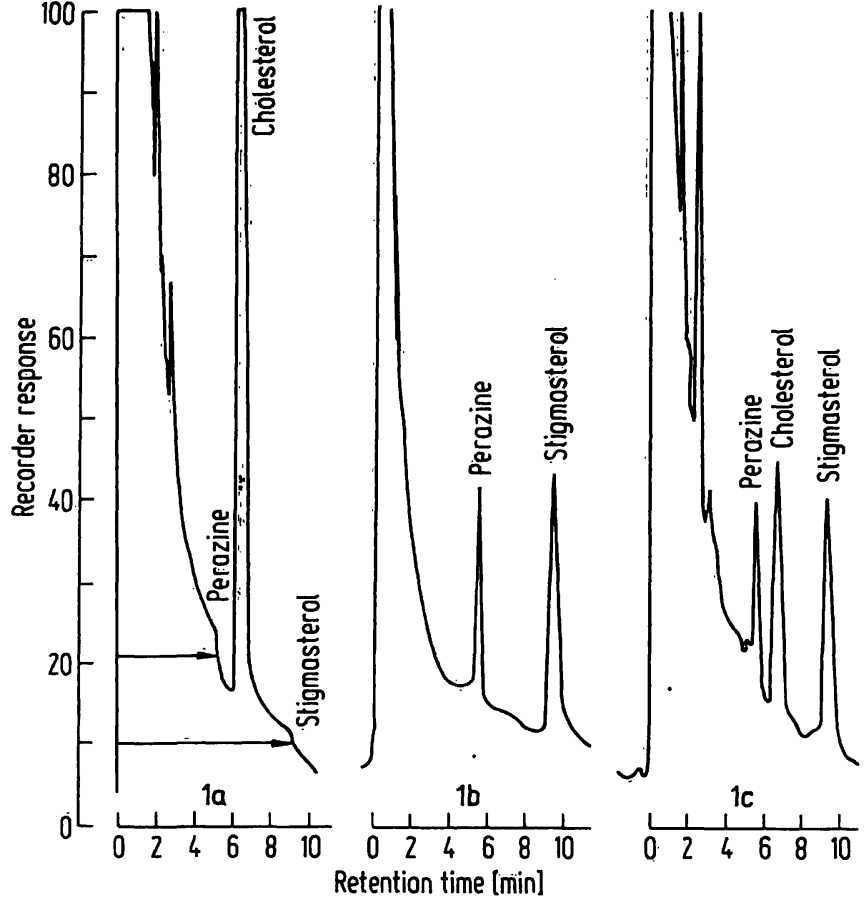

Fig. 1. Gas chromatogram (different series at different days).

1a: Blank serum

1 b: Perazine/stigmasterol in ethanolic solution on $3 \%$ silicone-OV-17 (Gaschrome Q, 100/120 mesh) Attenuation $8 \times 10^{-12} \mathrm{As}$

$1 \mathrm{c:}$ Serum of a patient treated with perazine Attenuation $8 \times 10^{-12} \mathrm{As}$

\section{Results and Discussion}

\section{Extraction procedure}

We investigated the distribution coefficients and elution characteristics of the following solvents: Methylene dichloride, chloroform, ethylene dichloride, benzene, toluene, $n$-heptane, $n$-heptane/isoamyl alcohol $(985 \mathrm{ml}$ $+15 \mathrm{ml}$ ) in relationship to the $\mathrm{pH}$ of the aqueous phase (4). $n$-heptane was found to be the most suitable solvent for the GLC procedure: at $\mathrm{pH} 10.4$ the distribution coefficient was 5.7 and the coextraction of serum factors was the lowest with regard of the temperature range used for perazine detection (fig. 1 a). Sufficiently low solubility of perazine base in water is achieved in an alkaline milieu, i.e. pH 8.5. Short heating of the alkalinized serum samples in a boiling water bath results in a better separation of the organic and the aqueous phase without loss of the drug (tab. 1). Inactivation of the surface of the glass vessels e.g. by silanization leads to considerably increased recovery values. The use of detergents for cleaning of the test tubes etc. must be avoided under any circumstances. Precleaning is done best by boiling with about $6 \mathrm{~mol} / \mathrm{l}$ hydrochloric acid.

\section{Optimization of the GLC system}

As stationary phases we have examined silicone-XE-60 and silicone-OV-17 (3\%) on Chromosorb G or Gaschrome $\mathrm{Q}(80 / 100$ or $100 / 120$ mesh resp.). Resolution with the $80 / 100$ mesh supports was lower and the loss of perazine greater than with the $100 / 120$ mesh ab-
Tab. 1. Recovery of perazine extracted from aqueous standard solutions or from spiked human sera under different analy tical conditions.

\begin{tabular}{|c|c|c|c|c|c|}
\hline $\begin{array}{l}\text { Perazine } \\
\text { concentration } \\
\text { [nmol/1] }\end{array}$ & $\begin{array}{l}\text { Recovery } \\
\text { From aqu } \\
\text { solution }\end{array}$ & $\begin{array}{l}\text { rate } \\
\text { leous }\end{array}$ & From s & ked & sera \\
\hline & $\begin{array}{l}\text { No treat- } \\
\text { ment }\end{array}$ & $\begin{array}{l}\text { Heated } \\
15 \mathrm{~min} \\
\text { at } 100^{\circ} \mathrm{C}\end{array}$ & $\begin{array}{l}\text { Heated } \\
\text { at } 100^{\circ}\end{array}$ & & in \\
\hline & & & $\begin{array}{l}\text { Unsilan } \\
\text { glasswa }\end{array}$ & ed & Silanized \\
\hline & $\mathbf{N}[\%]$ & $\mathbf{N}[\%]$ & $\mathbf{N}[\%]$ & & [\%] \\
\hline $\begin{array}{l}147.5 \\
295 \\
590\end{array}$ & $\begin{array}{ll}10 & 94 \\
15 & 86 \\
16 & 88\end{array}$ & $\begin{array}{ll}8 & 90 \\
7 & 89 \\
6 & 89\end{array}$ & $\begin{array}{ll}5 & 52 \\
6 & 53 \\
4 & 59\end{array}$ & $\begin{array}{l}8 \\
6 \\
6\end{array}$ & $\begin{array}{l}76 \\
73 \\
72\end{array}$ \\
\hline
\end{tabular}

sorbents. The most suitable stationary phase proved mesh. Optimization is achieved by determination of the Van Deemter hyperbolic function which relates the column efficiency - expressed as height equivalent to a theoretical plate (HETP) - to carrier gas flow changes; in addition, peak height, peak area and retention time were taken into consideration (fig. 2). Measurements were performed with standard solutions of 2.95 $\mathrm{mmol} / \mathrm{l}$ perazine in ethanol. The aim is to find the carrier gas flow rate at minimal retention time (in to be $3 \%$ silicone-OV-17 on Gaschrome Q 100/120 


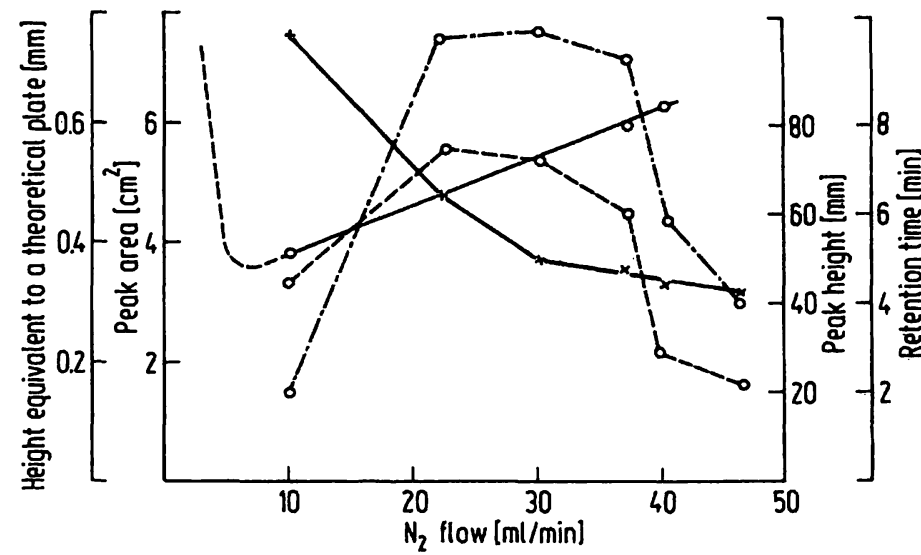

Fig. 2. Column efficiency (height equivalent to a theoretical plate HETP $0-0)$, peak height (0-.--0), peak area $(0---0)$ and retention time $(x-x)$ as a function of carrier gas flow $\left(\mathrm{N}_{2}\right)$. Analyses were performed with $2.95 \mathrm{nmol}$ perazine. Technical data ref. text.

order to increase the laboratory capacity) and at maximum peak height or area (in order to increase the sensitivity). From figure 2 it can be seen that it is not reasonable to make use of the highest possible separation performance (achieved at $\mathrm{u}=\leqslant 10 \mathrm{ml} / \mathrm{min}$ ), because then the peak height is too small and retention time too long. On the other hand, it does not make much sense to increase the carrier gas flow beyond $\mathrm{u}=30 \mathrm{ml} / \mathrm{min}$, because this does not result in a substantial reduction of the retention time, but in a considerable loss of sensitivity. Figure 2 shows that the optimal carrier gas flow for highest sensitivity and shortest retention time is $30 \mathrm{ml} / \mathrm{min}$. Another variable to be optimized is the column temperature. With increasing column temperature, peak heights are elevated and retention times shortened (fig. 3 ), thereby leading to an improved sensitivity and increased analytical capacity. If the full sensitivity of the chromatographic system is used the perazine

Tab. 2. Optimization of the GLC system.

Technical data ref. text. Analyses were performed with 2.95 nmol perazine.

$u \equiv$ carrier gas flow; $t_{R}=$ retention time

$P=$ peak height; $A=$ peak area; HETP $=1000 \mathrm{l} / \mathrm{N}$

$(1=$ column length $(m) ; N=$ number of theoretical plates $=16\left(\frac{t_{R}}{W}\right)^{2}$ with $W=$ peak width $(\mathrm{min})$.

All values are means from 3-10 single measurements.

\begin{tabular}{lcclll}
\hline $\mathbf{u}$ & $\begin{array}{l}\mathrm{t}_{\mathrm{R}} \\
{[\mathrm{m} / \mathrm{min}]}\end{array}$ & $\begin{array}{l}\mathrm{P} \\
{[\mathrm{min}]}\end{array}$ & $\begin{array}{l}\mathrm{A} \\
{\left[\mathrm{cm}^{2}\right]}\end{array}$ & $\begin{array}{l}\text { HETP } \\
{[\mathrm{mm}]}\end{array}$ & $\mathrm{N}$ \\
\hline 10 & 10.0 & 21 & 3.4 & 0.38 & 5000 \\
22 & 7.0 & 100 & 5.6 & 0.48 & 4000 \\
30 & 5.8 & 101 & 5.4 & 0.54 & 3500 \\
36 & 5.0 & 96 & 4.5 & 0.60 & 3200 \\
40 & 4.3 & 50 & 2.2 & 0.62 & 3100 \\
47 & 4.3 & 40 & 1.6 & 0.56 & 3400 \\
\hline
\end{tabular}

peak comes within the tailing of the solvent peak (at column temp. $>250^{\circ} \mathrm{C}$ ); electronic integration techniques are, therefore, not recommended. The quantitative evaluation should be done by comparison of the peak heights with those of an internal standard.

\section{Reproducibility}

Once the optimal values for the carrier gas flow and the column temperature have been determined, their daily control is essential for routine analytical work. This can be best achieved by setting up a calibration curve before every course of analysis. 29, 59, and $118 \mathrm{nmol}(=10,20$, or $40 \mu \mathrm{g}$, resp.) perazine were used with $48.46 \mathrm{nmol} / \mathrm{l}$ stigmasterol as internal standard (fig. 4). The evaluation by comparison of the peak heights does not give a linear calibration curve in all cases. The correct ratio between perazine and stigmasterol concentration in the solvent must be carefully checked. Evaporation of the solvent leads to a higher concentration and thereby to changes of the peak height ratio which may result into evaluation errors. Figure 5 shows the decrease of the peak height ratios with increasing concentration of perazine and stigmasterol in the ethanolic solution (at always the same concentration ratio $1: 1)$. Therefore, extracts which have been taken up with the standard solution should be kept cool $\left(0-4^{\circ} \mathrm{C}\right)$ and analysed the same day.

The recovery and the analytical error of analyses obtained with perazine-spiked blank sera can be seen from table 3. The quantitative evaluation of perazine determinations in serum is done by referring to the daily calibration curve and multiplication with the correction factor 1.35. The reproducibility of the method was also

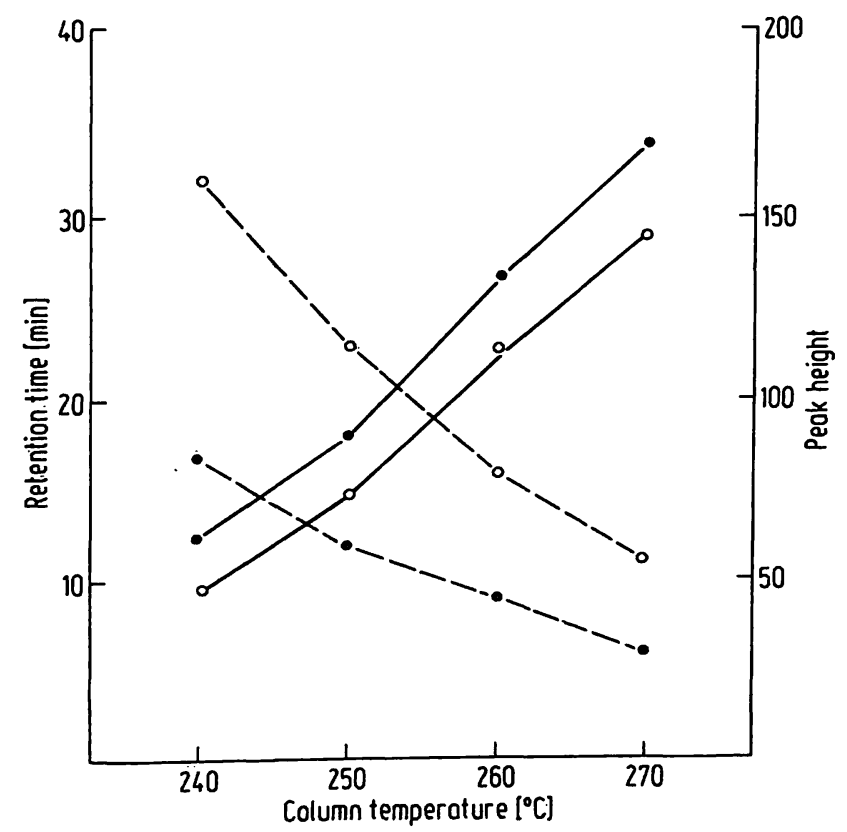

Fig. 3. Retention time (-- ) and peak height (-) of perazine $(\bullet)$ and stigmasterol $(0)$ as a function of the column temperature. Technical data ref. text. 


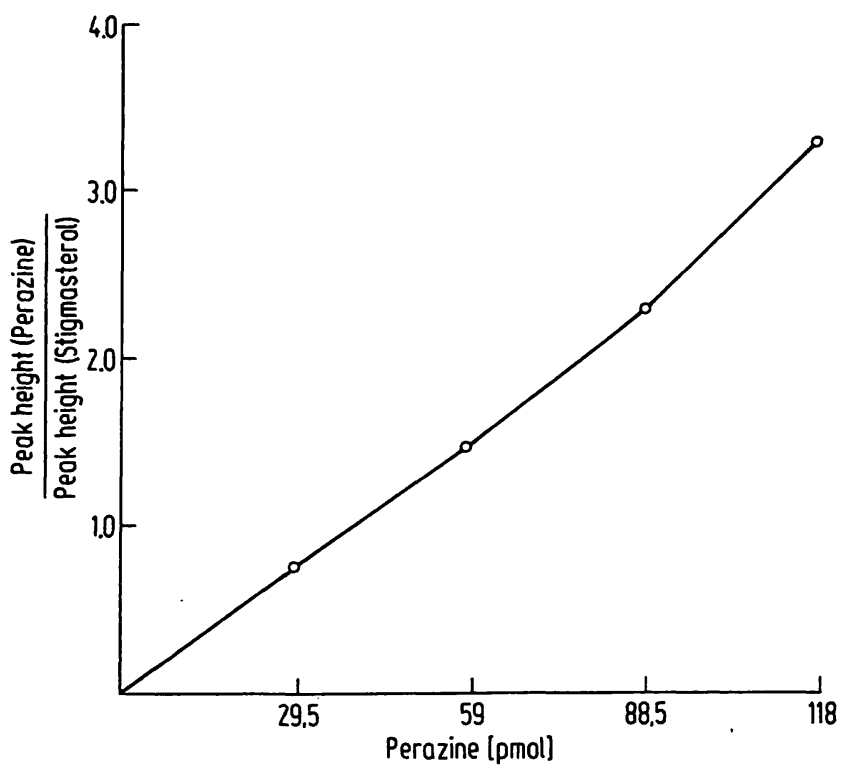

Fig. 4. Perazine calibration curve using peak height comparison with stigmasterol as internal standard.

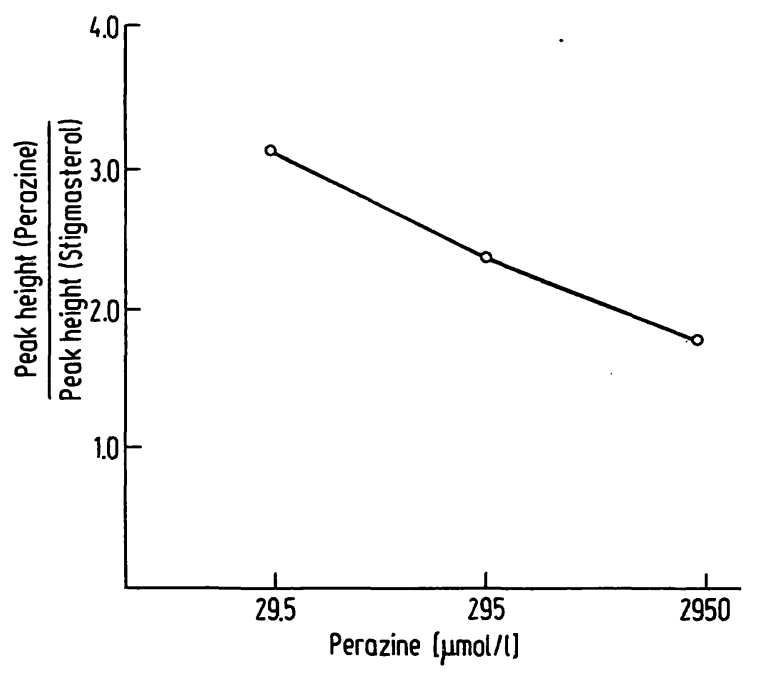

Fig. 5. Peak height ratio (ref. fig. 4) as a function of the concentration of perazine and stigmasterol $(1: 1)$ in the ethanolic solution.

Tab. 3. Recovery of perazine after extraction from spiked human blank sera.

\begin{tabular}{lrrlll}
\hline $\begin{array}{l}\text { Perazine } \\
\text { [nmol/1] }[\mu \mathrm{g} / 1]\end{array}$ & $\mathrm{N}$ & $\begin{array}{l}\text { Recovery } \\
\text { [nmol/1] } \\
\overline{\mathbf{x}} \pm \mathrm{s}_{\mathbf{x}}\end{array}$ & $\begin{array}{l}\text { Re- } \\
\text { cov- } \\
\text { ery } \\
\text { frac- } \\
\text { tion }\end{array}$ & $\begin{array}{l}\text { Correction } \\
\text { factor }\end{array}$ \\
\hline 147.50 & 50 & 8 & $112.10 \pm 14.36$ & 0.76 & 1.32 \\
295.00 & 100 & 17 & $216.91 \pm 36.81$ & 0.74 & 1.36 \\
590.00 & 200 & 6 & $419.02 \pm 51.62$ & 0.72 & 1.39 \\
\hline
\end{tabular}

examined by analysing the same serum samples twice, i.e. 14 samples which were split immediately after collecting the blood and processed independently of each other within an interval of 5-8 days. The mean difference
Tab. 4. Reproducibility of perazine determinations in serum samples of 14 out-patients. Each sample was analyzed twice (I-II) within 5-8 days.

\begin{tabular}{llllrl}
\hline Patient & $\begin{array}{l}\text { Pera- } \\
\text { zine I } \\
\text { [nmol/1] }\end{array}$ & $\begin{array}{l}\text { Pera- } \\
\text { zine II } \\
\text { [nmol/1] }\end{array}$ & Patient & $\begin{array}{l}\text { Pera- } \\
\text { zine I } \\
\text { [nmol/1] }\end{array}$ & \multicolumn{1}{l}{$\begin{array}{l}\text { Pera- } \\
\text { zine II } \\
\text { [nmol/1] }\end{array}$} \\
\hline D. M. & 100.30 & 103.25 & W. L. & 218.30 & 183.90 \\
K. J. & 171.10 & 162.25 & B. H. & 76.70 & 73.75 \\
B. G. & 227.15 & 212.40 & R. J. & 516.25 & 501.50 \\
K. B. & 182.90 & 171.10 & S. F. & 289.10 & 265.50 \\
N. D. & 398.25 & 377.60 & S. H. & 197.65 & 182.90 \\
K. W. & 454.30 & 442.50 & Z. A. & 286.15 & 271.40 \\
H. U. & 702.10 & 663.75 & P. H. & 59.00 & 44.25 \\
\hline
\end{tabular}

Tab. 5. Retention time $\left(t_{R}\right)$, peak height $(P)$ and relative peak height "P" as compared to perazine.

\begin{tabular}{lccc}
\hline Compound & $t_{R}[\mathrm{~min}]$ & $P[\mathrm{~mm}]$ & "P" \\
\hline Perazine & 6.0 & 198 & 1.00 \\
Desmethylperazine & 7.5 & 75 & 0.37 \\
Perazine sulfoxide & 23.0 & 30 & 0.15 \\
\hline
\end{tabular}

between the double determination was $17.38 \mathrm{nmol} / \mathrm{l}$ corresponding to a ratio of 0.065 between mean difference and mean value (tab. 4). The precision within one day was determined as $\mathrm{VK}=2.55 \%(\mathrm{~N}=6$; $\overline{\mathrm{x}}=364.3 \mathrm{nmol} / \mathrm{l}$; different extractions of one ponled sample). Relative retention time wạs 0.59 .

\section{Specificity}

The retention time of the following psychotropic compounds were determined and it was found that they do not interfere with the perazine measurement: butaperazine, trifluoperazine, levomepromazine, chlorpromazine, haloperidol, imipramine, amitriptyline, nortryptiline.

\section{Concluding remarks}

The lowest detection limit of the method as described above is appr. $60 \mathrm{nmol} / 1$. A clinical study which should demonstrate the practicability of the method under routine conditions, i.e. in perazine treated out-patients, has just been finished (6). Two main metabolites, desmethylperazine and perazine sulfoxide cannot be determined together with perazine in human sera. Perazine, desmethylperazine, and perazine sulfoxide are well separated from each other by this GLC procedure; however, the retention time of desmethylperazine is the same as that of a serum lipid peak, and the sensitivity of the system for the sulfoxide is about 6 times lower than for perazine. 
An independent GLC method for the determination of perazine in body fluids is thus available, in addition to the TLC method quoted above, thus providing the prerequisite for a systematic comparative control of these two clinical methods. Such internal comparative control by two independent methods appears to us much more relevant than the quality control by multicentered studies, which may result in a better comparability of the results of different laboratories, but which cannot exclude systematic analytical errors in the case of methods not yet standardized. The comparative study of Richens (7) provides much evidence for this argument. As the determination of neuroleptics or antidepressant drugs in human sera requires at least a 100 times higher

\section{References}

1. Breyer, U. \& Villumsen, K. (1976), Eur. J. Clin. Pharmacol. 9, 457-465.

2. Hadass, H., Kluwe, S. \& Fähndrich, Ch. (1972), Pharmakopsychiatr. 5, 53-69.

3. Breyer, U., Müller-Oerlinghausen, B. \& Mauruschat, W. (1976), in Psychotherapeutic Drugs (Forrest, I. S. \& Usdin, E., eds.), Marcel-Dekker, New York.

4. Müller-Oerlinghausen, B., Riedel, E. \& Schley, J. (1977), Int. J. Clin. Pharmacol. 15, 366-372. analytical sensitivity than in the case of anticonvulsant drugs, a rigid and comparative control of the methods is essential.

\section{Acknowledgements}

Thanks are due to Dr. $U$. Breyer for providing us with samples of desmethylperazinc and perazine sulfoxide. Perazine base was a gift from Promonta, Hamburg.

This work was supported by a grant from the Deutsche Forschungsgemeinschaft (,Klinische Pharmakologie“; He 916 ) $1-2$ ).
5. Vanderheeren, F. A. J., Theunis, D. J. C. J. \& Rosseel, M. T. (1976), J. Chromatogr. 120, 123-128.

6. Pietzcker, A., Schley, J. \& Müller-Ocrlinghausen, B. (1977), Arzneim.-Forsch. (Drug Res.), in press.

7. Richens, A. (1975), in Clinical Pharmacology of Anti-Epileptic Drugs (Schneider, H. et al., eds.), pp. 293-302, SpringerVerlag, Berlin.
Prof. Dr. E. Ricdel Institut für Biochemie der Freicn Universität Berlin Limonenstr. 7

D-1000 Berlin 45 
